\title{
Mapping and Prevalence of Malaria Falciparum Patients with ACT Failed Therapy, in Hanura Public Health Center, Pesawaran, Lampung, Indonesia
}

\author{
Jhons Fatriyadi Suwandi1,2*, Supargiyono ${ }^{3}$, Widya Asmara ${ }^{4}$, Hari Kusnanto ${ }^{5}$ \\ ${ }^{1}$ Department of Parasitology, Faculty of Medicine, University of Lampung, Bandar Lampung, Indonesia \\ ${ }^{2}$ Student of Doctoral Program, Faculty of Medicine, Gadjah Mada University, Yogyakarta, Indonesia \\ ${ }^{3}$ Department of Parasitology, Faculty of Medicine, Gadjah Mada University, Yogyakarta, Indonesia \\ ${ }^{4}$ Department of Microbiology, Faculty of Veterinary Medicine, Gadjah Mada University, Yogyakarta, Indonesia \\ ${ }^{5}$ Department of Public Health, Faculty of Medicine, Gadjah Mada University, Yogyakarta, Indonesia \\ Email:
}

Received 21 June 2014; revised 21 July 2014; accepted 21 August 2014

Copyright (C) 2014 by authors and Scientific Research Publishing Inc.

This work is licensed under the Creative Commons Attribution International License (CC BY). http://creativecommons.org/licenses/by/4.0/

(c) (i) Open Access

\section{Abstract}

Malaria is a public health issue that can cause death. According to the Indonesian Health Profile, in the year 2010, an estimated $45 \%$ of Indonesia's population live in malaria-endemic areas. Pesawaran District is one of the malaria-endemic areas in Lampung province, whose Annual Parasite Incidence in 2010 and 2011 were 2.77 and 4.76 respectively. One of the factors that may inhibit the malaria control is Plasmodium resistance to antimalarial drugs. This study aims to conduct a mapping study and see the prevalence of ACT treatment failure, in Pesawaran District, Lampung Province, Indonesia. Data collection was performed at the Primary Health Centers (PHC) Hanura. A total of 69 samples according to the inclusion and exclusion criteria, the microscopic examination serially for 28 days was done. Microscopic examination performed on D0, D1, D2, D3, D7, D14, D28, and a complaint is found outside the schedule. Coordinates of patient house, determined using GPS. Based on observations, microscopic examination and spatial analysis, the prevalence of ACT treatment failure in patients with falcipaum malaria was $11.59 \%$. The malaria falcifarum patient spread around the coast, that were near vector breeding places. There were five clusters of malaria falciparum patients and one cluster of malaria falciparum patient with treatment failure that were formed. Only one significant cluster of malaria falciparum patient $(P=0.0027$, radius 0 $\mathrm{km}$ ) is found, while the other cluster is not statistically significant. The cluster of malaria falcipa-

\footnotetext{
${ }^{*}$ Corresponding author.
}

How to cite this paper: Suwandi, J.F., Supargiyono, Asmara, W. and Kusnanto, H. (2014) Mapping and Prevalence of Malaria Falciparum Patients with ACT Failed Therapy, in Hanura Public Health Center, Pesawaran, Lampung, Indonesia. Open Journal of Epidemiology, 4, 169-177. http://dx.doi.org/10.4236/ojepi.2014.43023 
rum patient with treatment failure was not statistically significant $(P=1.000$, radius $0.15 \mathrm{~km})$, but this cluster is located in the area of the suspected vector breeding place. The cluster formation means that people living within a radius of these clusters have a greater risk to get malaria infection.

\title{
Keywords
}

\author{
Malaria Falciparum, Late Parasitological Failure, Mapping of Malaria Falciparum Patient, \\ Artemisinin Combination Theraphy
}

\section{Introduction}

Malaria is an infectious disease caused by Plasmodium sp. Plasmodium sp., is an intracellular parasite, which is transmitted by the bite of the female Anopheles mosquito. There are five species that can infect humans, namely: Plasmodium falciparum, Plasmodium vivax, Plasmodium malariae, Plasmodium ovale [1]-[6] and Plasmodium knowlesi [6]. The species most commonly found in Indonesia is $P$. falciparum and P. vivax [6]. Malaria is a public health issue that can causedeath, especially in high-risk groups such as infants, toddlers, and pregnant women. According to the Indonesian Health Profile, in 2010, an estimated 45\% of Indonesia's population live in malaria-endemic areas and $80 \%$ of districts/municipalities are malaria endemic area [7].

Lampung Province is one of the malaria-endemic areas in western Indonesia. Anual Parasite Incidence (API) of malaria in Lampung Province at 2007 until 2010 were reported 0.33; 0.33; 0.78 and 0.32 per 1000 population respectively [7]. This API value is still below the national average rate in 2010 (1.96 per 1000 population). Referring to the endemicity category issued by the Ministry of Health of the Republic of Indonesia, Lampung Province overall was a low endemic area [7]. However in several locations and districts, it still showed moderate to high endemicity such as Rajabasa subdistrict, South Lampung district and Padang Cermin and Punduh Pidada subdistrict, Pesawaran district [7]-[9]. Pesawaran District is one of the malaria-endemic areas as with moderate category in Lampung province. API values for Pesawaran District, in 2010 and 2011 respectively, are 2.77 and 4.76 [8]. Geographic conditions of Pesawaran District is an area of the coast, that had many puddles, and suitable for the breeding of Anopheles mosquitoes.

The persistently high incidence of malaria in several locations in Indonesia, including in Pesawaran District is very closely related to several factors, namely changes in the environment; high population mobility; climate change; nutritional status of the community; control programs and the factors of resistance to anti-malarial drugs

[9]. These factors either individually or collectively affect the transmission of malaria.

One of the factors that may inhibit the malaria control is Resistant of Plasmodium to antimalarial drugs. Indonesian Government was made a new policy in malaria treatment since chloroquine resistance spread to all region in Indonesion. Indonesian Health Ministry was used the Artemisinin Combination Therapy (ACT) as a standard of malaria treatment. ACT was used since 2004 and now had been implemented throughout the all province in Indonesia, include Pesawaran District [7]. Over time, the use of ACT in the Pesawaran District has demonstrated the possibility of $P$. falciparum resistance to the drug. Currently it has found patients who showed no clinical and laboratory improvement after treatment. In accordance with the WHO criteria in 2006, the treatment of malaria categorized into adequate clinical and parasitological response, early treatment failure and late treatment failure [10].

Mapping patterns of disease, based on a region, had often done to determine the areas as a point source of infection. Spatial analysis with geographical information systems approach (GIS) has been widely applied in various studies to control malaria. Abdullah (2008), Mendrofa (2008) and Sulistiowati (2011) [11]-[13], have been conducting research on spatial analysis of malaria patients on the environment in various regions in Indonesia. These studies had been mapped malaria patients and its relationship with environmental factors affecting the incidence of malaria. Mapping method that has been widely used can also be applied to mapping, malaria patients who failed therapy, so will facilitate monitoring of the patient.

This study aimed to determine the prevalence and mapping of malaria patients who experienced treatment failure of ACT, in Pesawaran District, Lampung Province, Indonesia. 


\section{Methods}

\subsection{Study Site and Sample}

This study was conducted at PHC Hanura, Padang Cermin subdistrict, Pesawaran district, which is a high malaria endemic areas, at the Pesawaran district. The population in this study were all patients with malaria, that were treated at PHC Hanura during 2012-2013. The study sample is a part of the population which in accordance with the inclusion and exclusion criteria. Inclusion criteria: 1) fever (temperature $>38^{\circ} \mathrm{C}$ ) over 2 days with or without chills; 2) positive falciparum malaria, based on microscopic examination of malaria; 3) more than 1 year old; and 4) be willing to follow the study by signing the informed concern. Exclusion criteria were 1) access to the patient's home, it is not possible to do; 2) have received anti-malarial treatment 1 - 2 weeks before; and 3) suffered from malaria complications/severe malaria/cerebral malaria that was not treated with ACT. In this study, the minimum sample size was calculated based on a sample size calculation formula and obtained the minimum sample size is 49.90 (55 samples) [14].

\subsection{Data Collection and Analysis}

Sampling was done at PHC Hanura, Pesawaran District, began in November 2012 until August 2013. Microscopic slides and microscopic examination were made and carried out in the Clinical Laboratory of PHC Hanura and confirmed in the Laboratory of Parasitology, Faculty of Medicine Gadjah Mada University.

The preparation of thin and thick blood smear, was made with reference to a standard peripheral blood collection. Thick and thin smears are allowed to dry at room temperature and then stained by Giemsa solution. Thin smears was done carefully fixation with absolute methanol (not to fixation of thick smear), then stained by $5 \%$ Giemsa for 30 minutes. After the staining is complete, the microscopic examination can be performed, with the objective lens $100 \times$ [15] [16].

Blood sampling for thin and thick smear performed serially for 28 days on D0, D1, D2, D3, D7, D14, D28, or when the patient was raised complaints/symptoms of malaria outside the predetermined schedule [15]. After taking the blood at D0, patients received treatment with standard drugs ACT. Response of therapy was assessed from the results of microscopic examination performed serially with reference to the WHO criteria, 2006 [10].

Microscopic examination aims to find P. falciparum, in the patient's blood and determined the density of Plasmodium per $\mathrm{mL}$ of blood. Parasitaemia counted per 200 leukocytes, and then times by the number of normal leukocytes (8000 leukocytes per $\mu \mathrm{L}$ of blood). parasitemia is the percentage of parasites (asexual stage) per 200 leukocytes [15] [16]. During the blood collection process, the identity of of patients, chief complaint, additional complaints, history taking of disease, treatment history, results of microscopic examination and other laboratory examinations, as deemed necessary, are recorded in patient medical record.

To taking coordinate point the study sample, carried out by using a GPS device. This tool will determine the coordinates of patient house, consisting of latitude and longitude. Place to take a coordinates, at a open area in front of the house and not blocked or not inside the room or under a roof. GPS device will read the coordinates, when it is connected to the satellite. The results, then stored for later use.

To determine the clinical condition or clinical symptoms were felt and complained, we made anamnesis, which recorded in the patient medical record. The chief complaint, additional complaints and history taking of disease of the patients were presented in frequency distribution table.

The data from the study are presented in descriptive, qualitative analysis and quantitative analysis. The analysis was done with the computer device. Grouping based on territorial and mapping, analysis with spatial analysis approach, using ArcGIS 10.1 software and Sat Scan software.

\subsection{Ethical Clearance}

This study has obtained the ethical approval (ethical clearance) for medical research from Health and Medical Research Ethics Committee, Faculty of Medicine, Gadjah Mada University. The respondents who participated in this study have also been given an explanation of the procedures that must be followed during the study and had also requested voluntary consent of the respondent at the beginning of its participation in this study.

\section{Results}

The research location is the southern area, in Pesawaran District, Lampung Province with an altitude of less than 
50 meters above sea level. The position coordinates of the location of the study is 05029 '53.666" to 0.315 05032'01" south latitude and 105014'20.944" to 0.516 105015'47" east longitude (Figure 1).

From all the data collected, 69 samples according to the inclusion and exclusion criteria. All of sample stayed in the Sukajaya Lempasing village, Padang Cermin subdistrict, Pesawaran district. Based on gender, the male is the largest group (57.97\%), the age more than 5 years old up to 25 years old is the largest group (66.66\%). For the clinical symptoms, the chief complaint most widely perceived by the respondents are fever (84.06\%). Various places that can potentially become Anopheles mosquito breeding places, were found around the residence of the respondents (Figure 2). A total of $84.06 \%$ of the sample, have a The distance between houses with mosquito breeding places are very close, which is 5 - 10 meters.

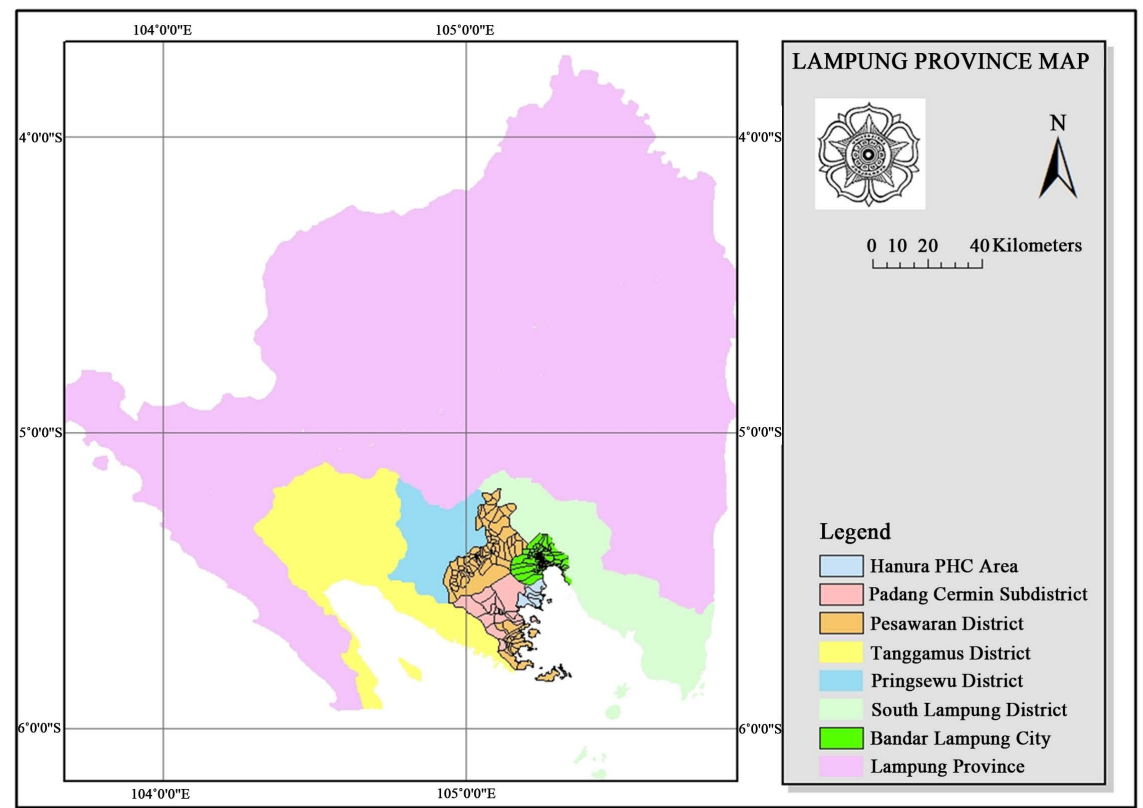

Figure 1. Map of study location in Padang Cermin subdistrict, Pesawaran district.

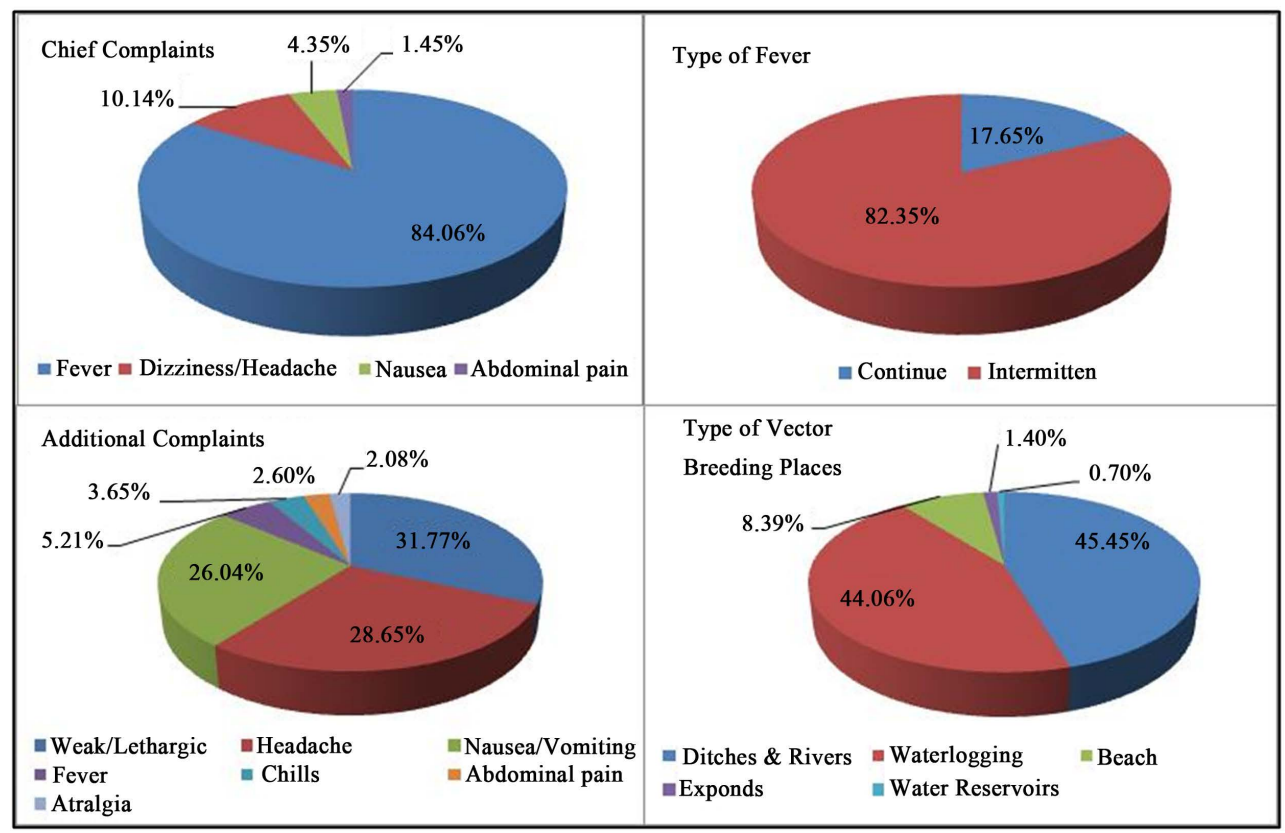

Figure 2. Clinical feature of malaria falciparum patients and type of potentially vector breeding place. 
Microscopic examination showed parasite density varies greatly, began from 16 to 11,440 parasites/ $\mu \mathrm{L}$ of blood. This parasite density is the density of parasites on microscopic examination of D0 by only counting asexual stage. There is only 1 respondent who found only gametocytes on microscopic examination. This parasite density tends to decrease throughout the day after treatment on D0. Based on WHO criteria, 61 respondents (88.41\%) in the category of Adequate Clinical and Parasitological response (ACPR). Early Treatment Failure (ETF) are not found in this study sample (Figure 3). Eight samples (11.59\%) were found positive return on microscopic examination in H14 (6 persons) and H28 (2 persons) who are classified as Late Parasitological Failure (LPF).

The starting time disappear asexual stage parasites in the blood occurred since D1 until D3 post-treatment. Disappearance of asexual stage parasites at 62 samples (89.86\%), occurred in D1 (Figure 3). Sexual stage (gametocytes) was found in 15 samples (21.74\%). Of the 15 samples found gametocytes, as much as two samples (13.33\%) persistent until D14, one sample (6.67\%) persistent until D7 and twelve samples (80\%), gametocytes had disappeared on day 3 (H3).

Figure 4 shows the distribution of the sample based on location of residence and buffering pattern. People were living within the buffer area, will be high risk for contracting malaria from existing patients. As it is known that the Anopheles mosquitoes had flight range distance until 3 kilometers. In this radius, the mosquitoes will fly and it was possible to transmit Plasmodium from one patient to the other man.

Clustering analysis performed using the software SatScan. Results of clustering analysis in patients with malaria, showed 5 clustering detected (Table 1). Figure 5 shows the location of the clusters and satellite image of this clusters.

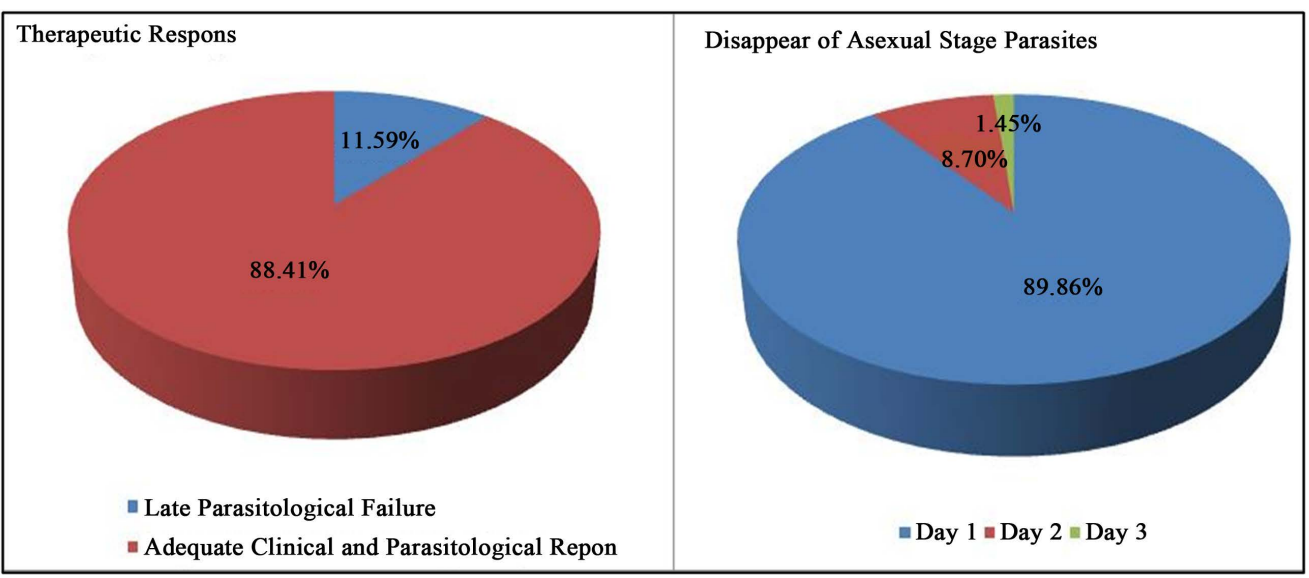

Figure 3. Therapeutic response and disappear of asexual stage parasites.
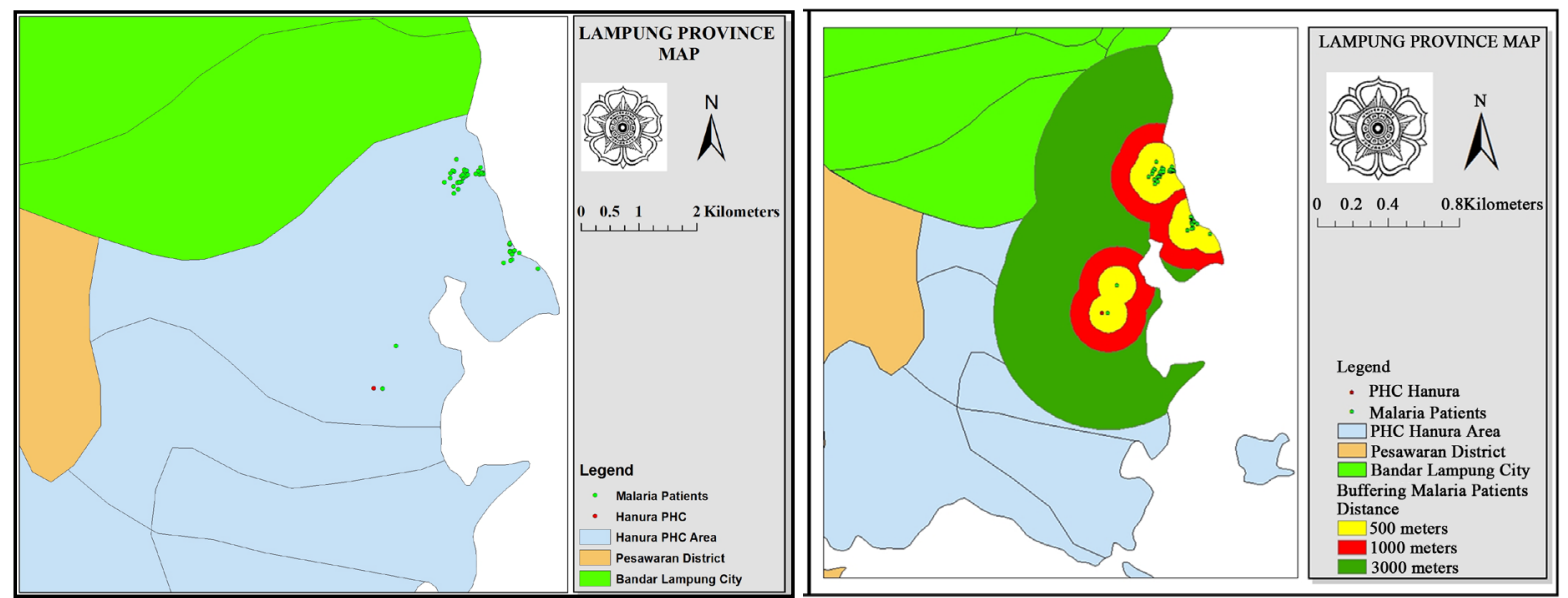

Figure 4. Distribution and buffering of malaria falciparum patients. 
Table 1. Results of clustering analysis in malaria falciparum patients.

\begin{tabular}{cccccc}
\hline No & Cluster & P value & Coordinates & Radius & Period \\
\hline 1 & 1 & 0.0027 & S 5.512458, E 105.258865 & $0 \mathrm{~km}$ & December 2012 until January 2013 \\
2 & 2 & 0.3030 & S 5.500311, E 105.254631 & $0.023 \mathrm{~km}$ & April 2013 \\
3 & 3 & 0.6160 & S 5.500377, E 105.249702 & $0.022 \mathrm{~km}$ & May 2013 \\
4 & 4 & 0.8940 & S 5.500832, E 105.252098 & $0.061 \mathrm{~km}$ & March 2013 \\
5 & 5 & 0.9450 & S 5.500112, E 105.251854 & $0 \mathrm{~km}$ & February until March 2013 \\
\hline
\end{tabular}

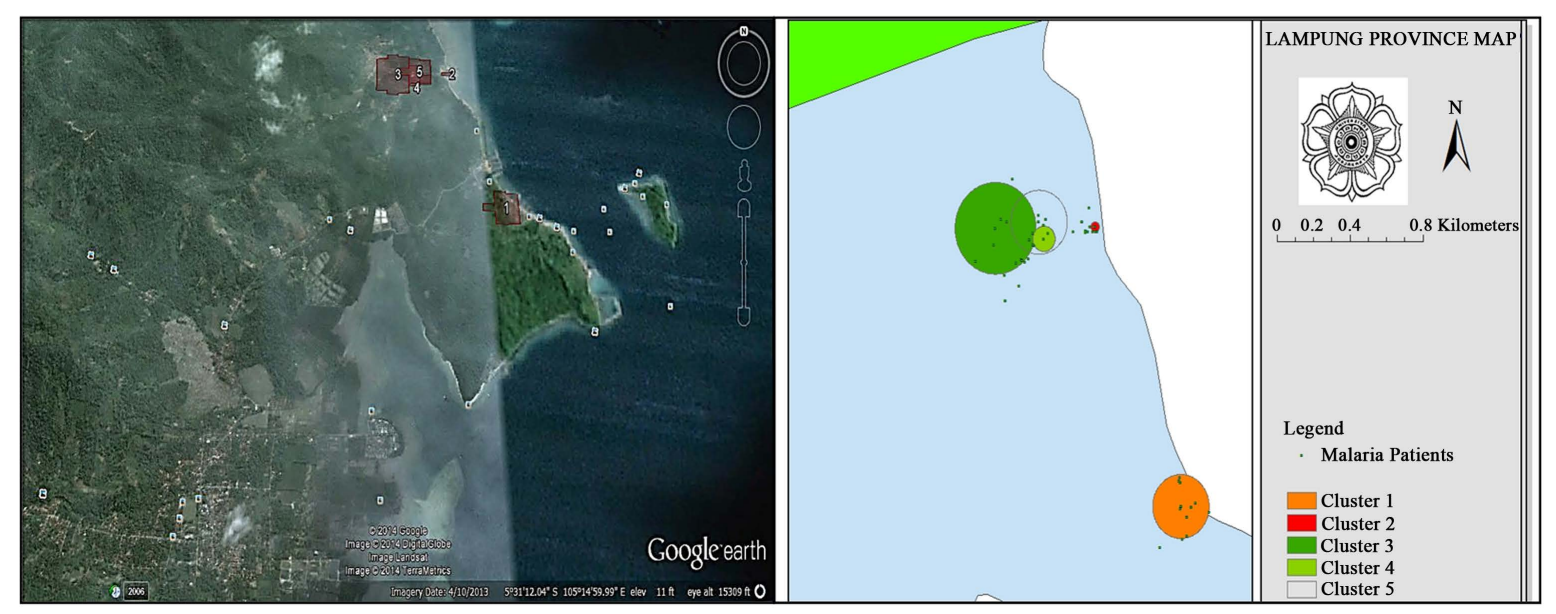

Figure 5. Clustering of malaria falciparum patients.

Distribution of patients with ACT failed therapy and the buffering pattern were shown in Figure 6. The buffering distance used the vector mosquito flight range (1 - $3 \mathrm{KM}$ ).

Results of clustering analysis at patients with ACT fail therapy showed only one cluster (Figure 7). The cluster has $\mathrm{P}=1.000$, with a radius of $0.15 \mathrm{~km}$ and located at coordinates S 5.500099, E 105.250258, which occurred during the period in May 2013.

\section{Discussion}

Patients with LPF category, most of the parasites appeared on day 14 and day 28. Absence of parasites on the examination day 2, 3 and 7 and appears again on day 14 and or 28, suggesting that the persistence of the parasite in blood, but the parasite density decreases so as not to be detected in microscopic examination. Plasmodium falciparum takes 24 - 72 hours to develop from the ring stage to a mature schizont stage. As is known, concentration of artemisinin (DHP or artesunate) in the blood will decrease rapidly after the third day of treatment. This is because, the half-time of artemisinin and its derivatives, only about 1 hour. Single treatment with artemisinin group was not less than 7 days or 3 days if given with combination long-acting antimalarial drugs [17]. Decreased of antimalarial concentration after the third day of treatment will provide sufficient time for the parasite are left to perform the process schizogony so in about 10 days already can be found parasites on microscopic examination.

The goal of radical therapy of malaria, is eliminating the asexual stages and sexual stages (gametocytes) from blood. As it has been known that gametocytes had an important role in the transmission of malaria infection. Gametocytes are infective Stadium to continue its development in the mosquito. The presence of gametocytes in the blood of patients showed there is still a source of infection. In this study there were 15 samples containing gametocytes, on microscopic examination. From follow-up found 2 patients, who gametositnya remained persistent until day 14.

Artemisinin, in previous studies [18], showed activity to decrease number of sexual stage (gametocytes) in the blood but not effect on mature gametocytes, so not all of gametocytes can be removed only by artemisinin ther- 


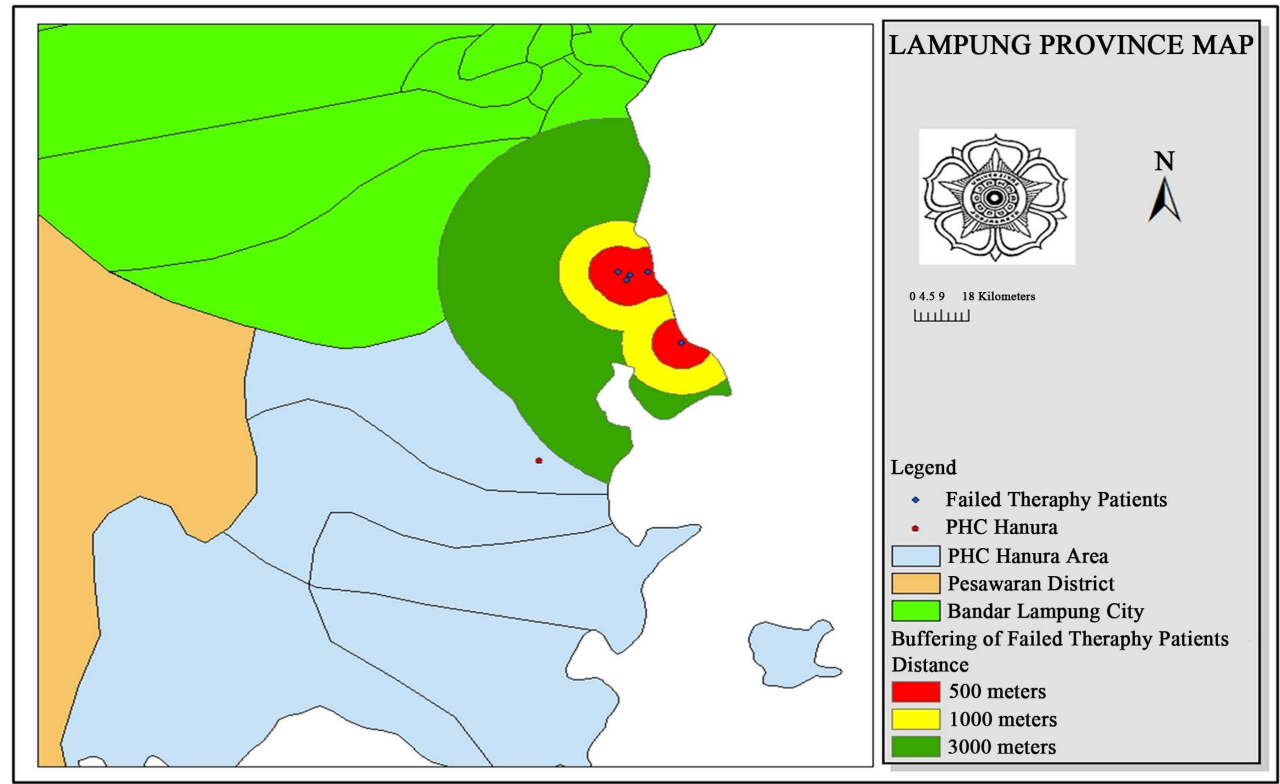

Figure 6. Buffering of malaria falciparum patients with treatment failure at Sukajaya Lempasing Village.
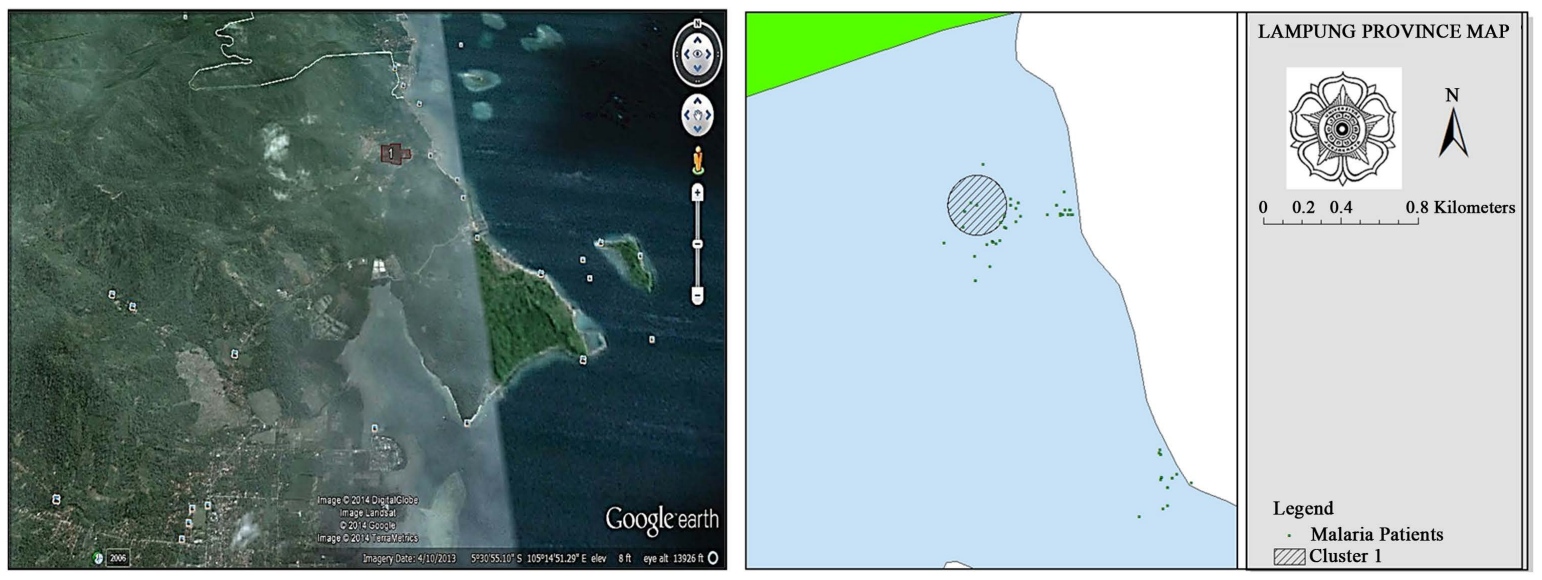

Figure 7. Clustering of malaria falciparum patients with treatment failure at Sukajaya Lempasing Village.

apy. The use of a single dose of primaquine $0.75 \mathrm{mg}$ base $/ \mathrm{kg}$ was needed to eliminate the sexual stage. Primaquine is one 8-aminoquinoline synthetic derivative, which effective against gametocytes and liver stage of $\mathrm{P}$. falciparum, but not in the blood stage. Mechanism of action of this drug is associated with primaquine conversion into a reactive oxygen (reactive oxygen species) and toxic metabolites on intracellular parasites. Mechanism of action of primaquine is also related to impaired function of ubiquinone, which is an essential electron carrier in the respiratory chain, in mitochondria [17] [19] [20].

Geographical conditions of Hanura health center area, was a coastal and hilly areas. On the east and southeast is an area of Lampung Bay. at West area was a plateau, mountain chain that separates this area from the district capital. In this region, there was several small estuaries and brackish water ponds, which were potential breeding places for the mosquito vector. Most malaria vectors found in the southern coast of Lampung is sundaicus Anopheles [21].

Distribution of malaria patients in this study as shown in Figure 4, most of the spread on the coast, in the village of Sukajaya Lempasing. There were only 2 cases, which residence did not near the coast. Location of residence of patients was an area with a dense population, the distance between the house less than 10 meters. Although, research conducted by Sulistyawati (2012) in Purworedjo did not showed significant relationship between the incidence of malaria with population density [22]. 
The buffer that formed on spatial analysis was shown in Figure 2. Buffer is an area with a risk of malaria transmission. As it is known that malaria transmission is very dependent on the presence of malaria vectors. Female mosquito of $A$. sundaicus can fly quite a distance, which is a maximum of up to $3 \mathrm{~km}$ [23]. Based on the distance of vector flight can be determined of buffer area of the source of infection. Shown in Figure 2, the location of the buffer extends, until out of the district Pesawaran. These conditions often lead to the transmission of the malaria is becoming widespread. As it is known, that the southern coastal areas of Bandar Lampung and Pesawaran are the malaria endemic spot area in Lampung province [24]. From these results, it is necessary to make cross-border planning so that it can control the spread of malaria in the south coast of Lampung Province.

In this study also seen the spread of malaria patients which failed therapy. From results of spatial analysis, it was found that the distribution of patients with treatment failure, are in areas with a high number of malaria patients. Buffer area looked extends, outside the Pesawaran district.

Buffer areas that form in Figure 2 and Figure 4, had an area that contained a pool of brackish water, ex ponds, rivers do not flow well, and a pool of sea water as a potential vector breeding places. Anopheles sundaicus is a mosquito, which had breeding places, in coastal areas and brackish water [23] [25]. This study was consistent with research Sulistiowati (2011) [13] which states that the spread of malaria in Sosoh Buay Rayap Sub district be close to the location of the vector mosquito breeding places. Research conducted by W. Zhang et al. (2008) [26] also showed that the spread of the malaria can be detected. The places of the risk of transmission can be predicted by using a spatial approach. SatScan analysis results, obtained 5 cluster of malaria distribution and 1 cluster of patients distribution with failed therapy. Only 1 cluster significant was found at distribution of malaria patients $(\mathrm{P}<0.005)$. This suggests that there has been a strong malaria transmission process in these cluster.

The results of the spasial analysis and mapping of malaria patients will be used as the basis of planning to prevent the spread of malaria infection in Lampung Province. The potential for the spread of malaria which can across administrative boundaries, environmental factors associated with vector breeding place, malaria patients as a source of infection, the mobility of people and many other factors, requires comprehensive malaria control planning, involving cross-sectoral and cross-border. This condition needs to be a concern of policy makers in malaria control, especially in Lampung Province and Indonesia in general.

\section{Conclusion}

The prevalence of ACT treatment failure in patients with falciparum malaria was $11.59 \%$ in PHC Hanura, Pesawaran, Lampung Indonesia. Five clusters of malaria falciparum patients and one cluster of malaria falciparum patients with failed therapy are found in PHC Hanura, Pesawaran, Lampung, Indonesia. Malaria patients clustered along the coast and located near the area as suspect vector breeding places.

\section{Acknowledgements}

We would like to thank the Government of the Pesawaran District, especially Pesawaran District Health Office, and staff of PHC Hanura, who have helped in the process of data collection. We also would like to thank the responders and volunteers who agreed to participate in this study. We also would like to thank to staff of Parasitology Laboratory, Faculty of Medicine, Gadjah Mada University and Laboratory of Geographic Information Systems, Faculty of Geography, Gadjah Mada University.

\section{References}

[1] Biggs, B.A. and Brown, G.V. (2001) Malaria dalam Principles and Practice of Clinical Parasitology. John Wiley \& Sons, LTD, Chichester.

[2] Centers for Disease Control and Prevention, "Malaria," 2012. http://www.dpd.cdc.gov/dpdx

[3] Garcia, L.S. and Bruckner, D.A. (1997) Diagnostic Medical Parasitology. 3rd Edition, ASM Press, Washington DC.

[4] Heelan, J.S. and Ingersoll, F.W. (2002) Essentials of Human Parasitology. Delmar Thomson Learning, Inc., Albany (NY).

[5] Markell, E.K., Voge, M. and John, D.T. (1986) Medical Parasitology. 6th Edition, WB Saunders Company, Philadelphia.

[6] Kemenkes, R.I. (2011) Pedoman Penatalaksanaan Kasus Malaria di Indonesia. Direktorat Jendral Pengendalian Penyakit dan Penyehatan lingkungan, Jakarta. 
[7] Kemenkes, R.I. (2011) Profil Kesehatan Indonesia Tahun 2010. Kementerian Kesehatan Republik Indonesia, Jakarta.

[8] Health Office of Pesawaran District (2012) Anual Parasite IncidensTahun 2010 dam 2011. Pesawaran, Lampung,

[9] Depkes, R.I. (2009) Profil Kesehatan Indonesia Tahun 2008. Departemen Kesehatan Republik Indonesia, Jakarta.

[10] WHO (2006) Guidelines for the Treatment of Malaria. WHO, The Institute, Geneva.

[11] Abdullah (2008) Analisis Spasial Kasus Malaria Pasca Tsunami di Kecamatan johan Pahlawan Kabupaten Aceh Barat Provinsi Nangroe Aceh Darussalam. Sekolah Pascasarjana Universitas Gadjah Mada, Yogyakarta.

[12] Mendrofa, E. (2008) Analisis Spasial Kasus Malaria di Kecamatan Lahewa Kabupaten Nias Provinsi Sumatera Utara Tahun 2006 dan 2007. Program Studi Ilmu Kesehatan Masyarakat Sekolah Pasca Sarjana Universitas Gadjah Mada, Yogyakarta.

[13] Sulistiowati, Z.D. (2011) Analisis Spasial Kejadian Malaria di Kecamatan Sosoh Buay Rayap Kabupaten Ogan Komering Ulu. Program Studi Ilmu Kesehatan Masyarakat Sekolah Pasca Sarjana Universitas Gadjah Mada, Yogyakarta.

[14] Lameshow, S., Hosmer Jr., D.W. and Lwanga, S.K. (1997) Besar Sampel Dalam Penelitian Kesehatan, Pertama. Gadjah Mada University Press, Yogyakarta.

[15] WHO (2003) Assessment and Monitoring of Antimalarial Drug Efficacy for the Treatment of Uncomplicated Falciparum Malaria. WHO, The Institute, Geneva.

[16] Wijayanti, M.A. and Murhandarwati, E.H. (2011) Modul Diagnosis Malaria Secara Mikroskopis. Bagian Parasitologi FK UGM, Yogyakarta.

[17] Waldman, S.A. and Terzic, A. (2009) Pharmacology and Therapeutics Principles to Practice. Saunders Elsevier, Philadelphia.

[18] Siswantoro, H., Hasugian, A.R., Avrina, R., Risniati, Y. and Tjitra, E. (2011) Efikasi dan Keamanan Dihidroartemisinin-Piperakuin (DHP) pada Penderita Malaria Falsiparum Tanpa Komplikasi di Kalimantan dan Sulawesi. Media Litbang Kesehatan, 21, 135-144.

[19] Katzung, B.G. (1998) Farmakologi Dasar dan Klinik, Edisi VI. EGC, Jakarta.

[20] Trevor, A.J., Katzung, B.G. and Master, S.B. (2002) Katzung and Trevor's Pharmacology. 6th Edition, Lange Medical Books/McGraw-Hill, New York.

[21] B2P2VRP (2012) Peta PEnyebaran Vektor Malaria Tahun 2012. Salatiga, Jawa Tengah.

[22] Sulistyawati (2012) Statistik Spasial Kepadatan Penduduk terhadap Kejadian Malaria di Kabupaten Purworejo dengan Menggunakan GIS. Jurnal Kesehatan Masyarakat, 6.

[23] Hiswani (2004) Gambaran Penyakit dan Vektor Malaria Di Indonesia. USU Digital Library Fakultas Kesehatan Masyarakat, Universitas Sumatera Utara, Medan.

[24] Suwandi, J.F. and Setyaningrum, E. (2009) Hubungan Prilaku Masyarakat Tentang Pengendalian Malaria Dengan Intensitas Transmisi Malaria Dengan Mendeteksi Gen MSP 1 Dan MSP 2 Menggunakan Metode PCR di Bandar Lampung. Bandar Lampung.

[25] Ariati, Y., Andris, H. and Sukowati, S. (2008) Bioekologi Vektor Malaria Nyamuk Anopheles sundaicus di Kecamatan Nongsa Kota Batam Tahun 2008. Jurnal Ekologi Kesehatan, 10, 29-37.

[26] Zhang, W., Wang, L., Fang, L., Ma, J., Xu, Y., Jiang, J., Hui, F., Wang, J., Liang, S., Yang, H. and Cao, W. (2008) Spatial Analysis of Malaria in Anhui Province, China. Malaria Journal, 7, 206. http://dx.doi.org/10.1186/1475-2875-7-206 
Scientific Research Publishing (SCIRP) is one of the largest Open Access journal publishers. It is currently publishing more than 200 open access, online, peer-reviewed journals covering a wide range of academic disciplines. SCIRP serves the worldwide academic communities and contributes to the progress and application of science with its publication.

Other selected journals from SCIRP are listed as below. Submit your manuscript to us via either submit@scirp.org or Online Submission Portal.
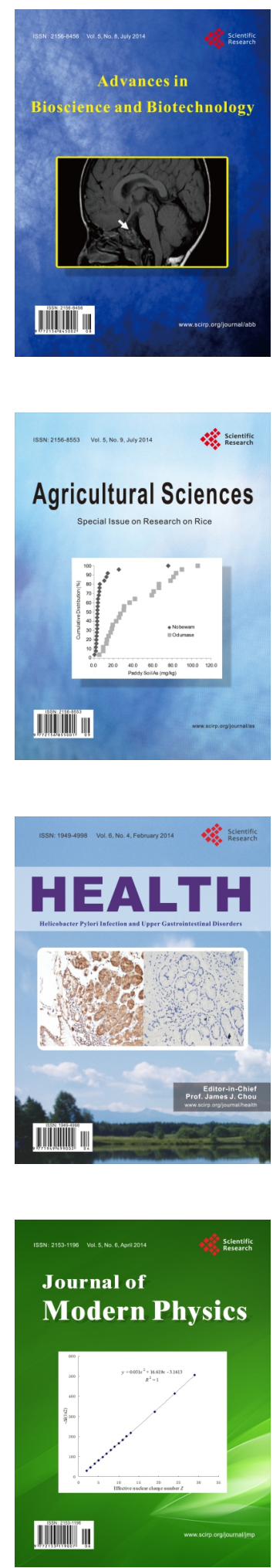
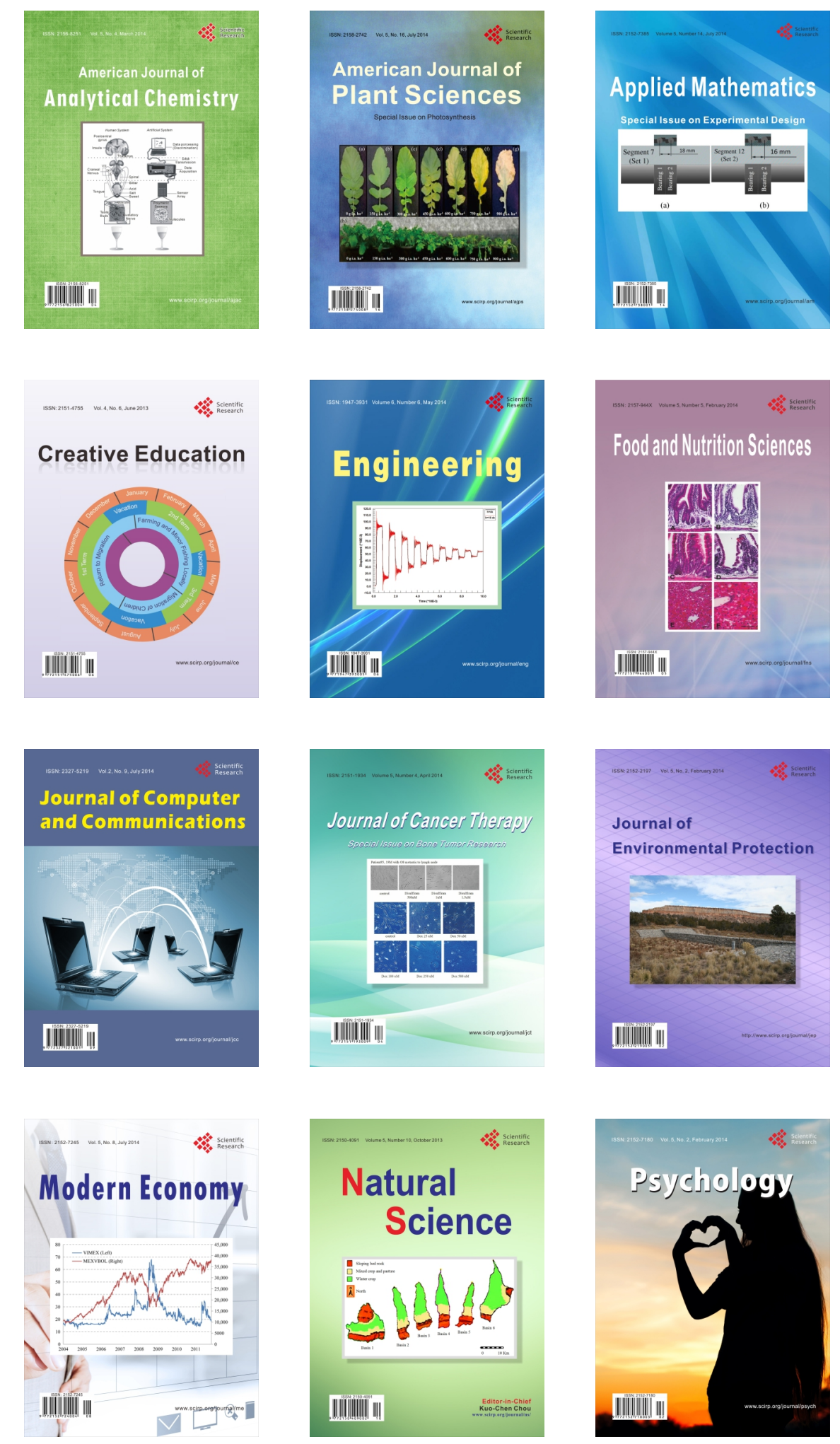